\title{
Floral ontogeny and vasculature in Xyridaceae, with particular reference to staminodes and stylar appendages
}

\author{
M. Graça Sajo ${ }^{1}$ Aline Oriani ${ }^{1} \cdot$ Vera L. Scatena $^{1} \cdot$ Paula J. Rudall $^{2}$ (1)
}

Received: 29 March 2017/ Accepted: 24 June 2017/Published online: 7 July 2017

(c) The Author(s) 2017. This article is an open access publication

\begin{abstract}
We provide a detailed comparative study of floral ontogeny and vasculature in Xyridaceae, including Xyris, Abolboda and Orectanthe. We evaluate these data in the context of a recent well-resolved phylogenetic analysis of Poales to compare floral structures within the xyrid clade (Xyridaceae and Eriocaulaceae). Xyrids are relatively diverse in both flower structure and anatomy; many species incorporate diverse and unusual floral structures such as staminodes and stylar appendages. Xyridaceae possess three generally epipetalous stamens in a single whorl; the "missing" stamen whorl is either entirely absent or transformed into staminodes. Fertile stamens each receive a single vascular bundle diverged from the median petal bundle. In Xyris, the stamen bundle diverges at the flower base, but it diverges at upper flower levels in both Abolboda and Orectanthe. In species of Abolboda that possess staminodes, staminode vasculature is closely associated with the lateral vasculature of each petal. Despite the likely sister-group relationship between Eriocaulaceae and Xyridaceae, our character optimization indicates that the stylar appendages that characterize some Xyridaceae (except Xyris and Achlyphila) are non-homologous with those of some Eriocaulaceae. On the other hand, it remains equivocal whether the loss of a fertile outer androecial whorl occurred more than once during the
\end{abstract}

Handling Editor: Louis P. Ronse De Craene.

Paula J. Rudall

p.rudall@kew.org

1 Instituto de Biociências, Universidade Estadual Paulista (UNESP), Rio Claro, SP CEP 13506-900, Brazil

2 Royal Botanic Gardens, Kew, Richmond, Surrey TW9 3AB, UK evolutionary history of the xyrid clade; this transition occurred either once followed by a reversal to fertile stamens in Eriocauloideae and staminodes in some Xyridaceae, or twice independently within both Xyridaceae and Eriocaulaceae.

Keywords Flower anatomy · Poales · Stamens · Stylar appendages · Vasculature

\section{Introduction}

The commelinid monocot family Xyridaceae consists of five genera that are mostly neotropical, though the largest genus Xyris extends to other regions of the southern hemisphere (Table 1). The family is highly recognizable in morphological terms, often possessing ensiform leaves and imbricate-bracted spikes with showy flowers with only three antepetalous fertile stamens (Kral 1998), in contrast with the typical six-staminate condition that predominates in most other monocots (e.g. Remizowa et al. 2010). In many other monocot families with only three stamens, such as Iridaceae and Mayacaceae, the stamens are opposite the outer tepals; i.e. antesepalous (e.g. Carvalho et al. 2009; Ronse de Craene 2010; Oriani and Scatena 2012). Xyridaceae are currently circumscribed into two subfamilies: Xyridoideae, with a single widespread genus Xyris L. (ca 360 species), and Abolbodoideae, with four genera endemic to South America (Table 1). The family Xyridaceae belongs in the order Poales and is probably most closely related to Eriocaulaceae (e.g. Davis et al. 2004; Givnish et al. 2010; Barrett et al. 2015). Xyridaceae flowers are hermaphrodite, but Eriocaulaceae flowers are generally unisexual by late abortion of the stamens or carpels, resulting in female or male flowers, respectively (Stützel 
Table 1 Genera of Xyridaceae

\begin{tabular}{lll}
\hline Genus & No. of species & Distribution \\
\hline Abolboda Kunth & ca. 22 & Central and South America \\
Achlyphila Maguire and Wurdack & 1 & Endemic to Guiana Highlands \\
Aratitiyopea Steyerm. and P.E.Berry & 1 & Rocky outcrops in NW Brazil, SW Venezuela and SE Colombia \\
Orectanthe Maguire & 2 & Endemic to Guiana Highlands \\
Xyris L. & ca. 360 & Mostly in Neotropics: Central and South America, Africa, Australia
\end{tabular}

Data from Dahlgren et al. (1985), Kral (1998) and Campbell (2005)

1998). Both Xyridaceae and Eriocaulaceae-collectively termed the "xyrids" — are unusual in possessing only three fertile stamens, at least in some species (in Eriocaulaceae, the number of androecial whorls is reduced in only one of the two subfamilies, Paepalanthoideae; some Eriocaulaceae are also dimerous). Another commelinid family with only three stamens, Mayacaceae (with a single genus, Mayaca), was formerly included among the xyrids (e.g. Linder and Rudall 2005), but a recent molecular analysis (BouchenakKhelladi et al. 2014) has tentatively placed Mayacaceae closer to Rapateaceae (Fig. 1).

A colourful, showy perianth and nectar production from septal nectaries are both likely ancestral conditions for monocots (Remizowa et al. 2010). Many Poales are characterized by flowers that differ from "typical" monocot flowers in several traits that are sometimes associated with wind pollination. These features include petals that are nonshowy and often reduced in size and/or number, absence of nectaries and a reduced number of stamens (Linder and Rudall 2005). Species of Xyridaceae are biotically pollinated but lack septal nectaries; their flowers are relatively showy, possessing a double (heterochlamydeous) perianth

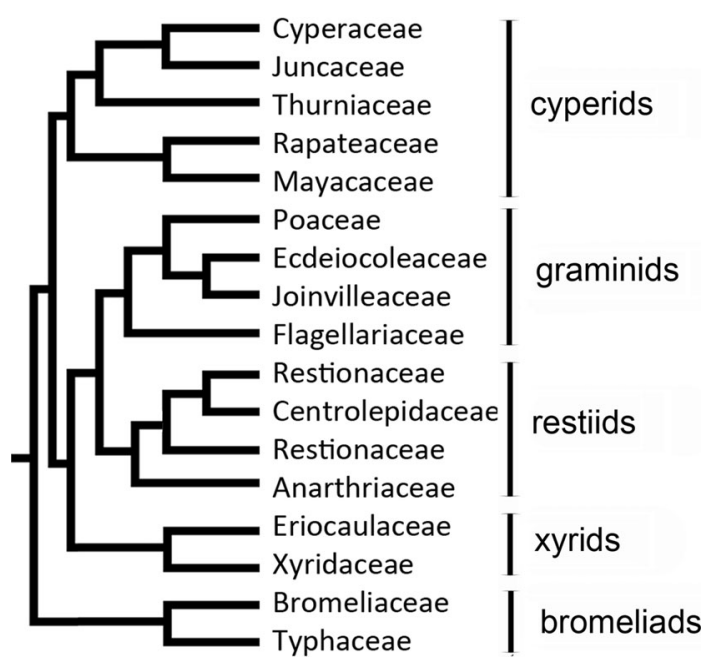

Fig. 1 Tree diagram summarizing relationships between families of Poales, as suggested by molecular analysis in Bouchenak-Khelladi et al. (2014) of green sepals and colourful petals (Rudall and Sajo 1999; Oriani and Scatena 2012). The absence of septal nectaries in both Xyridaceae and Eriocaulaceae has prompted some authors to speculate that nectaries have evolved de novo in xyrids from ancestors that lacked septal nectaries (Linder and Rudall 2005). Both Abolbodoideae (Xyridaceae) and Paepalanthoideae (Eriocaulaceae) have flowers with stylar appendages that produce nectar, which is used as a resource by insect pollinators (Rosa and Scatena 2007; Oriani et al. 2009; Oriani and Scatena 2011, 2012).

In this paper, we examine the floral vasculature of six species of Xyridaceae, representing three genera: Abolboda, Orectanthe and Xyris (Fig. 2). The other two genera (Achlyphila and Aratitiyopea) are both monotypic and are relatively rare; for these two species, we rely on earlier descriptions. Floral vasculature of Abolboda, Achlyphila and Orectanthe was described by Carlquist (1960), and flowers of Aratitiyopea were described by Campbell and Stevenson (2007). Oriani and Scatena (2012) also provided information on floral anatomy of Abolboda and Orectanthe. Our primary goals are to elucidate familial systematics and the possible origin of the staminodial whorl that is present in Xyris and some species of Abolboda (Table 2). A staminodial whorl is a relatively unusual feature in monocots with hermaphrodite flowers (e.g. Walker-Larsen and Harder 2000). Sajo et al. (1997) and Remizowa et al. (2012) reported an unusual pattern of perianth vasculature in Xyris species: each sepal receives a single bundle and each petal receives three bundles, in contrast with many other heterochlamydeous angiosperms, in which the sepals typically receive three bundles each, whereas the petals receive a single major vascular bundle at the base (Eames 1931; Puri 1951; Endress 2001, 2005).

Vasculature has been used in combination with other characters to infer that the petals are broadly homologous with staminodes (i.e. sterile stamens) because the stamens also typically receive a single vascular bundle; in contrast, sepals are considered to be derived from leaf-like bracts (reviewed by Remizowa et al. 2012). The unusual vasculature of Xyris, together with the absence of staminodes and presence of a floral tube in Orectanthe, Aratitiyopea 

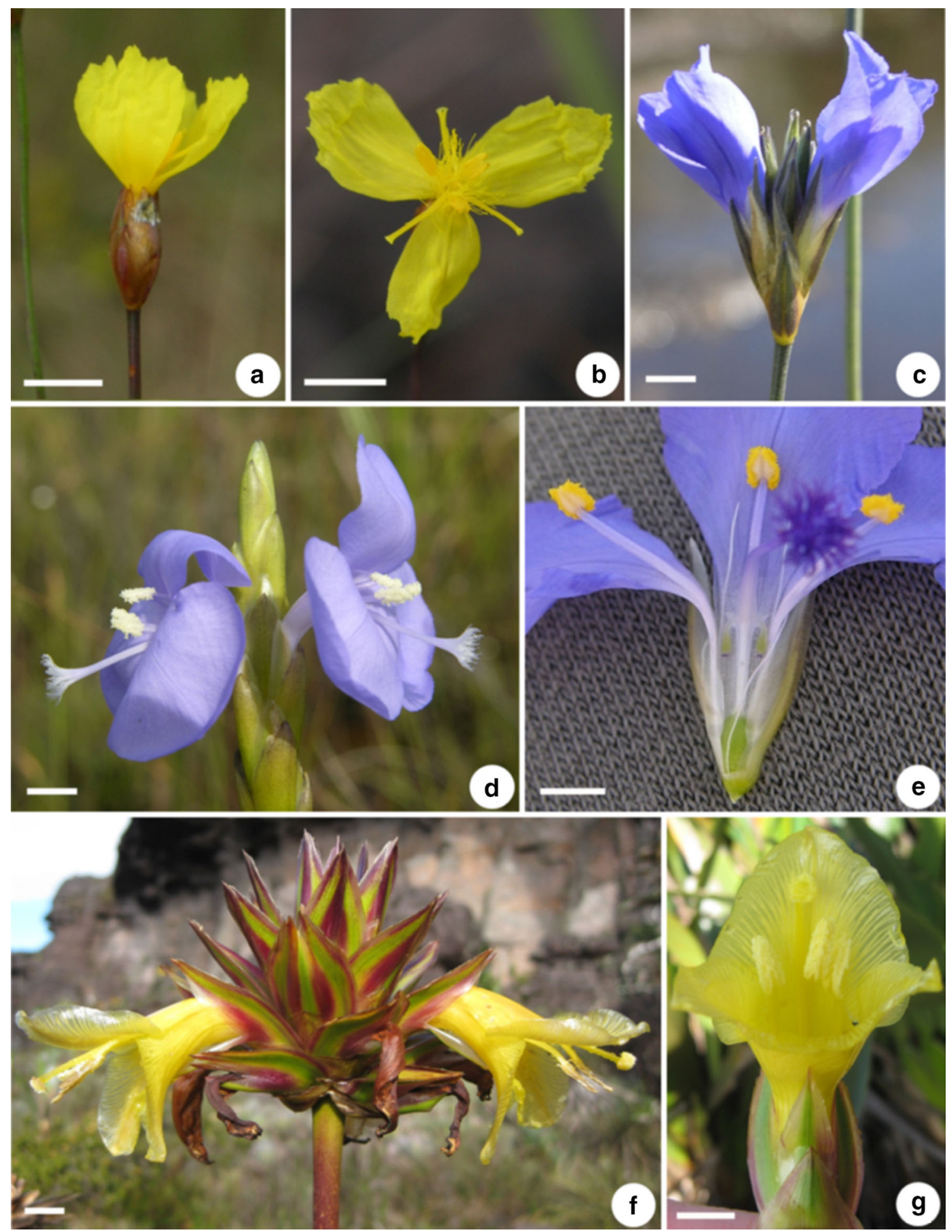

Fig. 2 Photographs of flowers; a, b Xyris sp., three showy petals and three plumose staminodes; c, e Abolboda poarchon, blue/purple petals fused at the base; d Abolboda macrosthachya; $\mathbf{f}, \mathbf{g}$ Orectanthe sceptrum, globose spikelet. Bars $\mathbf{a}-\mathbf{d}=5 \mathrm{~mm} ; \mathbf{e}=2.5 \mathrm{~mm} ; \mathbf{f}, \mathbf{g}=1 \mathrm{~cm}$

and most species of Abolboda, prompted Sajo et al. (1997) to propose that during evolution, the three "missing" stamens could have become incorporated into the corolla in the species that lack staminodes. However, this hypothesis previously lacked corresponding data from the vasculature of Abolbodoideae. To clarify this problem, we here include species of Abolboda both with staminodes (A. poarchon, A. macrostachya) and without staminodes (A. pulchella). 


\section{Materials and methods}

Species were collected from their natural habitats under permit, as listed in Table 2. Material was fixed in formalinacetic alcohol (FAA) and stored in 50\% ethanol. For light microscopy (LM), some flowers were embedded in paraplast using standard methods and serially sectioned at ca $13 \mu \mathrm{m}$ thickness using a rotary microtome. Sections were mounted onto microscope slides, stained in safranin and Alcian blue, dehydrated through an ethanol series to $100 \%$ ethanol, transferred to Histoclear, and mounted in DPX mounting medium (distrene, with dibutyl phthalate and xylene). Some flowers of Abolboda poarchon and Orectanthe sceptrum were embedded in resin using Leica Historesin. Sections were stained with periodic acid-Schiffs reagent and toluidine blue and mounted in Entellan rapid mounting medium (a methacrylate polymer). Slides were examined using a Leica DMLB photomicroscope fitted with a Zeiss Axiocam digital camera.

For scanning electron microscope (SEM) examination, fixed spikelets and florets were carefully dissected in $70 \%$ ethanol and then dehydrated in an ethanol series to $100 \%$ ethanol. They were then critical-point-dried using a BalTec 030 critical point dryer, mounted onto pin stubs, coated with platinum using an Emitech K550 sputter coater, and examined using a Hitachi cold field emission SEM S-4700 at $2 \mathrm{kV}$.

For character optimization (Fig. 11), we used WinClada (Nixon 2002) under three cladistic optimality criteria: (a) unambiguous changes, (b) ACCTRAN (accelerated transformation), which favours reversals over parallelisms, and (c) DELTRAN (delayed transformation), which favours parallelisms over reversals.

\section{Results}

\section{Flower organization (Fig. 2)}

Flowers in Xyridaceae are organized in a spike inflorescence (Fig. 2c, d, f). A single bract encloses each flower in Abolboda, Orectanthe and Xyris (Figs. 2d, f, 3a, 6a, 8g).
Fig. 3 Xyris spp. (SEM), stages of flower differentiation; a dissected inflorescence with flower buds at different development stages: bud 1 with three sepal and three petal primordia, bud 2 with enlarged sepal and petal primordia, bud 3 with three congenitally merged carpels surrounding a central dome; $\mathbf{b}$ detail of flower 2 in (a); $\mathbf{c}$ later stage with bifurcated staminodes and extrorse anthers; d fused carpels enclosing differentiating ovules; e two flower buds, lower one with sepals removed; f gynoecium with three stylodia; $\mathbf{g}$ dissected ovary showing orthotropous ovules basally attached. Labels: $\mathrm{c}=$ carpel; ov $=$ ovule, $\mathrm{p}=$ petal $; \mathrm{s}=$ sepal $; \mathrm{st}=$ stamen $; \mathrm{stn}=$ staminode; sty $=$ stylode. Bars $=100 \mu \mathrm{m}$

The three petals are yellow in Orectanthe and Xyris, and blue/purple in Abolboda (Fig. 2). The sepals are free from each other and of unequal size and shape: the two ventral (adaxial) sepals are conspicuous, coriaceous and more developed than the dorsal (abaxial) sepal, which is membranaceous in Xyris and Abolboda (Figs. 6c-e, 9a, b), or entirely absent in A. poarchon (Fig. 7b, c). Similarly, in Orectanthe, the two adaxial sepals are more developed than the abaxial sepal (Fig. 10a, b). Stamen number differs between species (Table 3), but all species possess three carpels.

\section{Flower development (Figs. 3, 4, 5)}

Three sepals are initiated on a dome-shaped floral primordium, as two adaxial triangular primordia and one abaxial bar-shaped bulge (Fig. 3a, flower 1). Very soon after sepal initiation and alternating with them, three rounded compound petal-stamen primordia are initiated (Figs. 3a, 4a). In Xyris (Fig. 3b, c) and some species of Abolboda (A. poarchon, A. macrostachya, Fig. 4b), three small staminode primordia are initiated opposite the sepals; they differentiate at the same time as the petal primordia in Xyris, but after sepal and petal differentiation in Abolboda. In all species examined, each petal-stamen primordium enlarges and subsequently becomes subdivided by a constriction into an outer petal and inner stamen primordium (Figs. 3b, 4b, 5b).

The sepals and petals grow rapidly, covering the rest of the flower and protecting the developing parts (Figs. 3c-f, 4c). They possess a broader base than the other floral

Table 2 Material examined

\begin{tabular}{ll}
\hline Species & Collector and number \\
\hline Abolboda macrostachya Spruce ex Malme & Lombardi et al. 7538, 7539 \\
Abolboda poarchon Seub. & Coan and Oriani 61, 72 \\
Abolboda pulchella Bonpl. & Coan and Oriani 60, 71 \\
Orectanthe sceptrum (Oliv.) Maguire & Lombardi et al. 7658, Scatena et al. 472 \\
Xyris savanensis Miq. & Coan and Oriani 84 \\
Xyris sp. & Coan et al. 77 \\
\hline
\end{tabular}

Voucher specimens are deposited at the Herbarium Rioclarense (HRCB) 

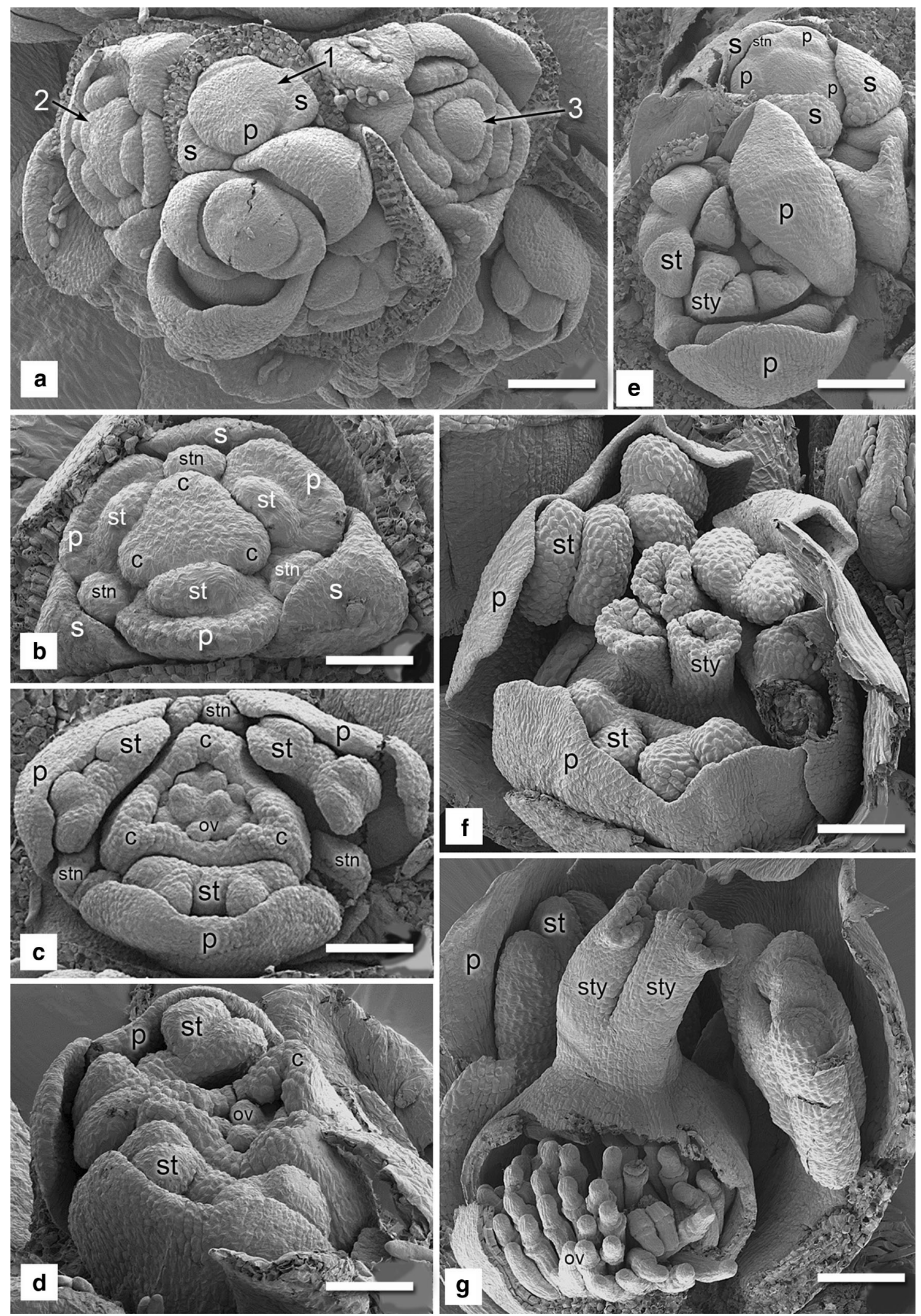
organs and encircle the floral bud, enclosing the other organs (Figs. 3e, f, 4b, c). The staminode primordia soon cease elongation and differentiate into a bifurcated structure in Xyris (Fig. 3c), or a filiform structure in Abolboda (Fig. 4c, e). The three functional stamen primordia elongate and develop four microsporangia that are mostly extrorse in both Xyris and Abolboda (Figs. 3c, d, 4c, d) and introrse in Orectanthe Figs. 5e, f, 10h).

There is a long plastochron between perianth/androecium differentiation and gynoecial initiation, during which the centre of the floral meristem enlarges (Fig. 3b). Subsequently, the gynoecium is initiated as three bulges opposite the sepals (Fig. 3b) that give rise to the style branches (Fig. 3c-e). The ovary and style emerge as a tubular structure by intercalary growth. In Xyris, the ovary is unilocular and its outer walls extend upwards (Fig. 3c, d). Subsequently, three stylodia are formed, initially as triangular mounds on the tips of the ovary (Fig. 3e, and then extend upwards (3f, g). In Abolboda and Orectanthe, three stylar appendages are differentiated on the dorsal side of each carpel at a relatively late stage in flower development (Figs. 4d, e, 5e, f). In Xyris, many ovule primordia develop on a basal placenta within the ovary (Fig. 3d). Subsequently, they extend upwards as orthotropous ovules (Fig. 3g). In Abolboda and Orectanthe, ovules are inserted on axile placentae and curve to become anatropous (Figs. 4f, 10e).
Fig. 4 Abolboda macrostachya (SEM); a dissected inflorescence with three flower buds: one (left) undifferentiated, one (centre) with a bract primordium, one (right) with three sepal primordia (only two visible) and three petal primordia; b, c later stages with enlarged sepals and petals, sepals removed in c; d later stage showing developing gynoecium with stylar appendages; e later stage showing stylar appendages, ramified stigma and filiform staminodes; $\mathbf{f}$ dissected ovary showing anatropous ovules. Labels: ap = stylar appendage; $\mathrm{c}=$ carpel; ov $=$ ovule, $\mathrm{p}=$ petal; $\mathrm{s}=$ sepal; $\mathrm{st}=$ stamen; stg $=$ stigma; $s$ sn $=$ staminode. Bars $=100 \mu \mathrm{m}$

In Abolboda and Orectanthe, the merged petal bases extend axially by intercalary growth, ultimately giving rise to a gamopetalous corolla tube that represents a common stamen-petal tube (hypanthium) (Fig. 2e, g).

\section{Flower anatomy (Figs. 6, 7, 8, 9, 10)}

In some Abolboda species (A. macrostachya and A. pulchella), the abaxial sepal is reduced and unvascularized (Fig. 9a). In Xyris, the petals are entirely free, but in Orectanthe and Abolboda they are fused together into a tube at their bases (Figs. 2e, g, 10f, g). In Xyris, the petals alternate with three plumose staminodes that are divided at their apices (Fig. 6f, g). Conspicuous staminodes are absent in Orectanthe and in most species of Abolboda, though filiform structures occur in the staminode position

Table 3 Floral characters that differ between genera of Xyridaceae

\begin{tabular}{|c|c|c|c|c|c|}
\hline & $\begin{array}{l}\text { Abolboda (anatomical data } \\
\text { from Carlquist 1960; Oriani } \\
\text { and Scatena 2012; and this } \\
\text { paper) }\end{array}$ & $\begin{array}{l}\text { Achlyphila } \\
\text { (anatomical } \\
\text { data from } \\
\text { Carlquist } \\
\text { 1960) }\end{array}$ & $\begin{array}{l}\text { Aratitiyopea } \\
\text { (anatomical data } \\
\text { from Campbell } \\
\text { and Stevenson } \\
\text { 2007) }\end{array}$ & $\begin{array}{l}\text { Orectanthe (anatomical } \\
\text { data from Carlquist 1960; } \\
\text { Oriani and Scatena 2012; } \\
\text { and this paper) }\end{array}$ & $\begin{array}{l}\text { Xyris (anatomical data from } \\
\text { Sajo et al. 1997; Rudall and } \\
\text { Sajo 1999; Remizowa et al. } \\
2012 \text {; and this paper) }\end{array}$ \\
\hline Sepals & $\begin{array}{l}\text { 3; abaxial sepal smallest or } \\
\text { absent; adaxial sepals with } \\
3+\text { vbs }\end{array}$ & $\begin{array}{l}3 \text {; each with } \\
3+\mathrm{vbs}\end{array}$ & $\begin{array}{l}3 \text {; abaxial sepal } \\
\text { smallest; adaxial } \\
\text { sepals supplied } \\
\text { by } 3+\text { vbs }\end{array}$ & $\begin{array}{l}\text { 3; abaxial sepal smallest; } \\
\text { adaxial sepals with } \\
3+\text { vbs }\end{array}$ & $\begin{array}{l}\text { 3; abaxial sepal smallest; } \\
\text { adaxial sepals supplied by } 1 \\
\text { vascular bundle }\end{array}$ \\
\hline Petals & $\begin{array}{l}\text { 3, basally fused; supplied by } \\
5 \text { vbs in } A \text {. poarchon and } \\
\text { A. pulchella, } 7-9 \text { vbs in } A \text {. } \\
\text { macrostachya }\end{array}$ & $\begin{array}{l}\text { 3, free; } \\
\text { supplied by } \\
3 \mathrm{vbs}\end{array}$ & $\begin{array}{l}\text { 3, basally fused; } \\
\text { supplied by } \\
\text { many vbs }\end{array}$ & $\begin{array}{l}3 \text {, basally fused; supplied } \\
\text { by } 7-9 \text { vbs }\end{array}$ & 3 , free; supplied by $3 \mathrm{vbs}$ \\
\hline Stamens & 3 , epipetalous & 3 , epipetalous & 3 , epipetalous & 3 , epipetalous & 3 , epipetalous \\
\hline Staminodes & $\begin{array}{l}0(\text { A. pulchella }) \text { or } 3(A . \\
\text { poarchon, } A . \\
\text { macrostachya })\end{array}$ & 0 & 0 & 0 & $\begin{array}{l}\text { 3, conspicuous, plumose, on } \\
\text { the outer stamen whorl }\end{array}$ \\
\hline $\begin{array}{l}\text { Stylar } \\
\text { appendages }\end{array}$ & Present & Absent & Present & Present & Absent \\
\hline $\begin{array}{l}\text { Ovary } \\
\text { placentation }\end{array}$ & Axile & Axile & Axile & Axile & $\begin{array}{l}\text { Basal, or axile in some } \\
\text { species }\end{array}$ \\
\hline Ovary locules & Incompletely trilocular & $\begin{array}{l}\text { Incompletely } \\
\text { trilocular }\end{array}$ & $\begin{array}{l}\text { Incompletely } \\
\text { trilocular }\end{array}$ & Incompletely trilocular & Unilocular \\
\hline Ovules & Anatropous & Anatropous & Anatropous & Anatropous & Orthotropous \\
\hline
\end{tabular}

Data sources morphological data from Kral $(1992,1998)$ and this paper; anatomical data as cited in table 

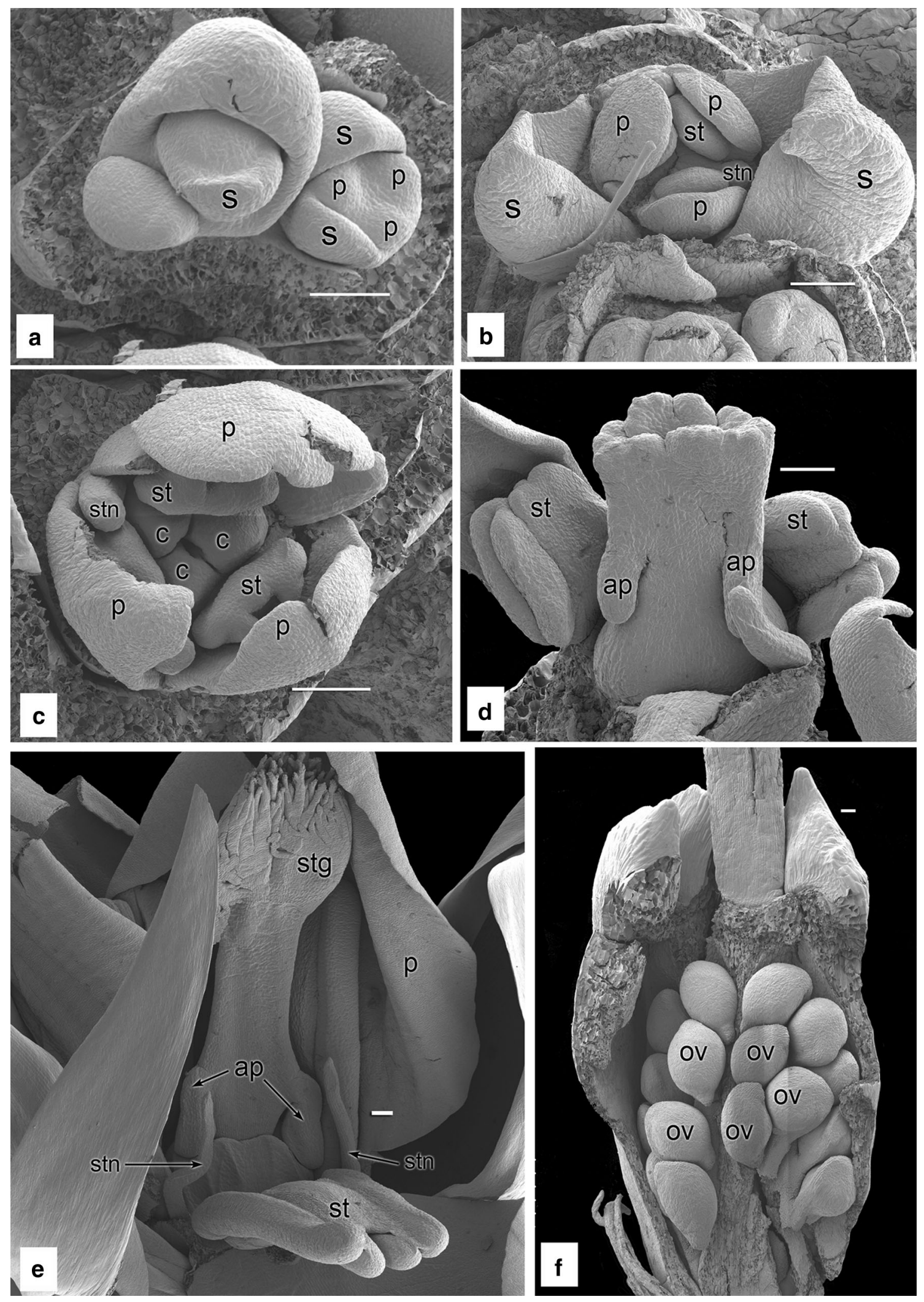

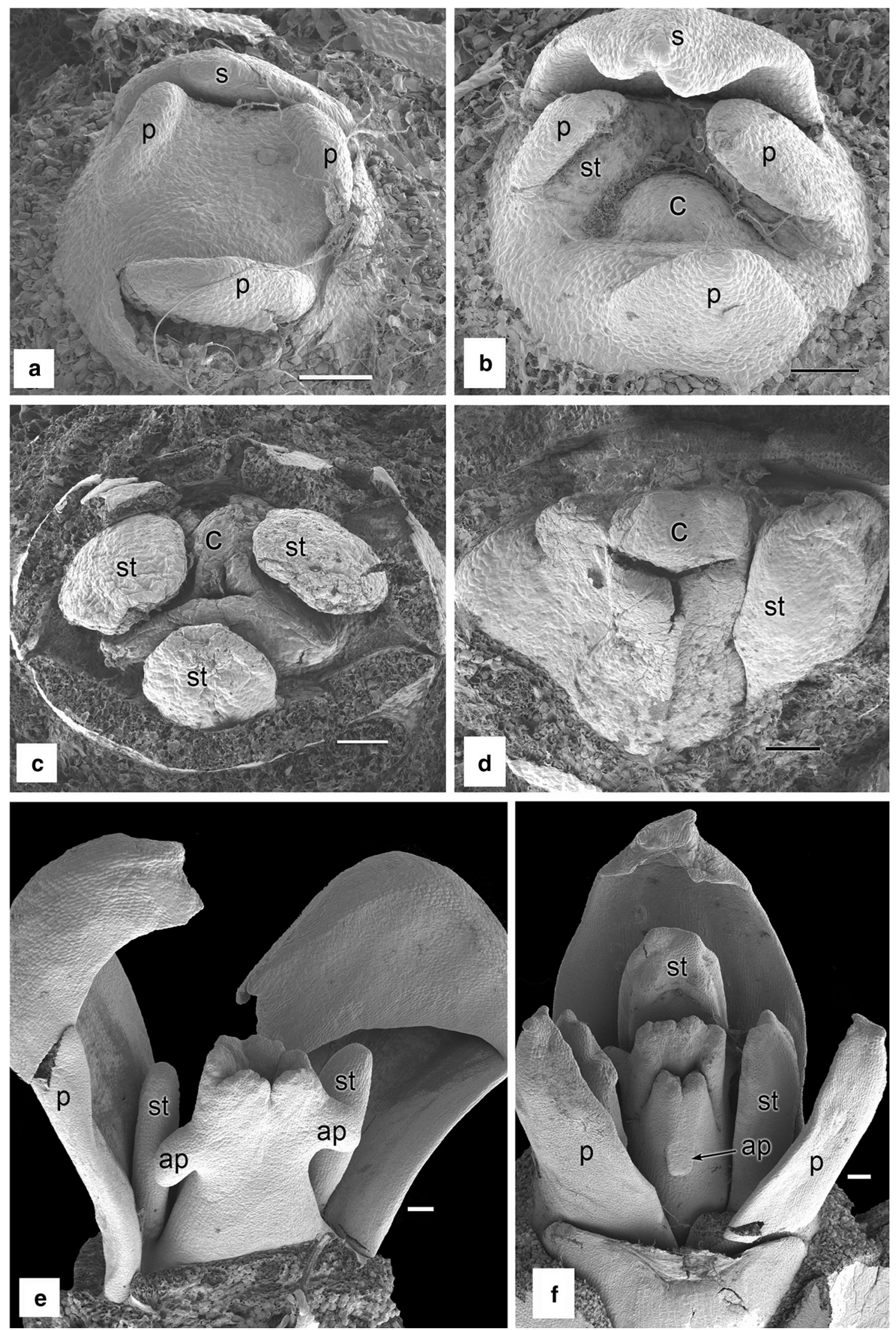
4Fig. 5 Orectanthe sceptrum (SEM); a bud with three sepal primordia and three petal primordia; b bud with one developed sepal (the other two removed), stamen primordia adjacent to petals and three carpel primordia (two not visible), hypanthial growth has also occurred; c later stage with sepals and petals removed showing stamens and carpels; $\mathbf{d}$ carpels congenitally fused at base; e, f later stages with sepals removed showing petals, stamens, and gynoecium with stylar appendages. Labels: ap $=$ stylar appendage; $\mathrm{c}=$ carpel; $\mathrm{p}=$ petal; $\mathrm{s}=$ sepal; st $=$ stamen. Bars $=100 \mu \mathrm{m}$

in A. macrostachya (Figs. 4e, 8a, b) and A. poarchon (Figs. 2e, 7c).

The three functional stamens are adnate to the petals in all species examined; the anthers are dorsifixed in Abolboda (Figs. 4d, 8d) and basifixed in Xyris and Orectanthe (Figs. 3g, 6f). Anthers are tetrasporangiate and the endothecium possesses wall thickenings. Anthers are extrorse in both Xyris and Abolboda (Figs. 3g, 4d) and introrse in Orectanthe (Fig. 10h).

The ovary is superior and tricarpellate. It is unilocular in Xyris (Fig. 3c, g) and incompletely trilocular in both Abolboda and Orectanthe (Figs. 8a, b, 10d).

In Xyris, the single style is hollow and tripartite at the tip with each branch bearing a single stigma (Figs. 3f, g, 6g, h); the inner stylar epidermis is slightly papillate (Fig. $6 \mathrm{~g}, \mathrm{~h}$ ). In Abolboda and Orectanthe, the style is hollow at the base (Figs. 8c, 10f) and solid at the apex (Figs. 8e, 10g); the stigma branches at the apex in both Abolboda (Fig. 4e) and Orectanthe (Fig. 5f). In Abolboda and Orectanthe, the style possesses three vascularized appendages (Figs. 8e, 10f, g).

\section{Flower vasculature (Figs. 6, 7, 8, 9, 10)}

Xyris

Each sepal is supplied by a single vascular bundle (Fig. 6c). Each petal receives three bundles (Fig. 6d, e). Each stamen and staminode is supplied by a single vascular bundle (Fig. 6d, e). The gynoecium has three dorsal carpellary bundles and many ventral carpellary bundles that supply the ovules (Fig. 6e).

At the flower base, four groups of vascular bundles, consisting of three peripheral groups and a central cylinder (Fig. 6b), give rise to the vasculature of all flower parts. Each peripheral group (encircled in red in $6 b$ ) divides into four bundles: an outer bundle that supplies the sepal (Fig. 6c-f) and three inner and parallel bundles that supply the staminodes opposite the sepals and the sides of two adjacent petals (Fig. 6d-f). From the central vascular cylinder (encircled in yellow in $6 \mathrm{~b}, \mathrm{c}$ ), the median petal bundle diverges (Fig. 6c); this bundle divides to supply the adnate stamens (Figs. 6d-f). The remaining bundles of the central cylinder supply three dorsal carpellary bundles located opposite the sepals and staminodes (Fig. 6d-f) plus the ventral carpellary bundles that supply the ovules (Fig. 6d). The dorsal bundles run throughout the style and supply the three stigmas (Fig. 6g, h). Each lateral petal bundle, originating from the same bundle group as the staminodes, ramifies in the petal.

\section{Abolboda}

Each sepal is supplied by several vascular bundles (Figs. 7b, c, 9b). In A. macrostachya and A. pulchella, the abaxial sepal is reduced and unvascularized (Fig. 9a). Each petal receives 5-7 bundles (Figs. 7c, 8a, b, 9b). Each stamen and staminode is supplied by a single vascular bundle (Fig. 8b, c). The gynoecium has three dorsal bundles (Figs. 7b, c, 8a, 9b) and many ventral bundles that supply the ovules (Figs. 7b, c, 9b).

At the flower base, there is a ring of vascular bundles that supplies the bundles for the lateral parts of the adaxial sepals. The vascular ring reorganizes into four vascular complexes: three peripheral and one central (Fig. 7a). In $A$. poarchon and $A$. macrostachya, which possess staminodes, each peripheral complex (encircled in red in Fig. 7a) gives rise to the median sepal bundle, the staminode bundle that lies opposite the sepal and the lateral bundles of two contiguous petals (Fig. 7b, c). In A. pulchella, which lacks staminodes (as in most species of this genus), each peripheral complex (encircled in red in Fig. 7a) supplies the median sepal bundle and the lateral bundles of two adjacent petals (Fig. 9a), which ramify in the petal (Fig. 9b). In all species, the bundles of the central vascular complex (encircled in yellow in Figs. 7a, 9a) supply the median petal bundles and the dorsal and ventral carpel bundles (Figs. 7b, c, 9b).

The dorsal carpellary bundles run throughout the style (Fig. 8c-e) and supply both the stylar appendages (Fig. 8d, e) and the stigma (Fig. 8f). The ventral carpellary bundles supply the anatropous ovules within the ovary (Fig. 8a, b). At the top of the ovary, the median petal bundle diverges to supply the adnate functional stamen (Fig. 8c). The lateral petal bundles originate from the same vascular group as the central sepal bundle and staminodes (when present); the lateral petal bundles ramify at upper levels (Fig. 8c, d). The abaxial sepal is reduced and unvascularized in A. macrostachya and $A$. puchella (Fig. 9a) and absent in A. poarchon (Fig. 7a-c).

\section{Orectanthe}

Each sepal is supplied by several vascular bundles (Fig. 10a, b). Each petal receives several bundles (Fig. 10a-c). Each stamen is supplied by a single vascular bundle (Fig. 10d, f-h). The gynoecium has three dorsal bundles (Fig. 10c, d) and many ventral bundles that supply the ovules (Fig. 10c, d). 

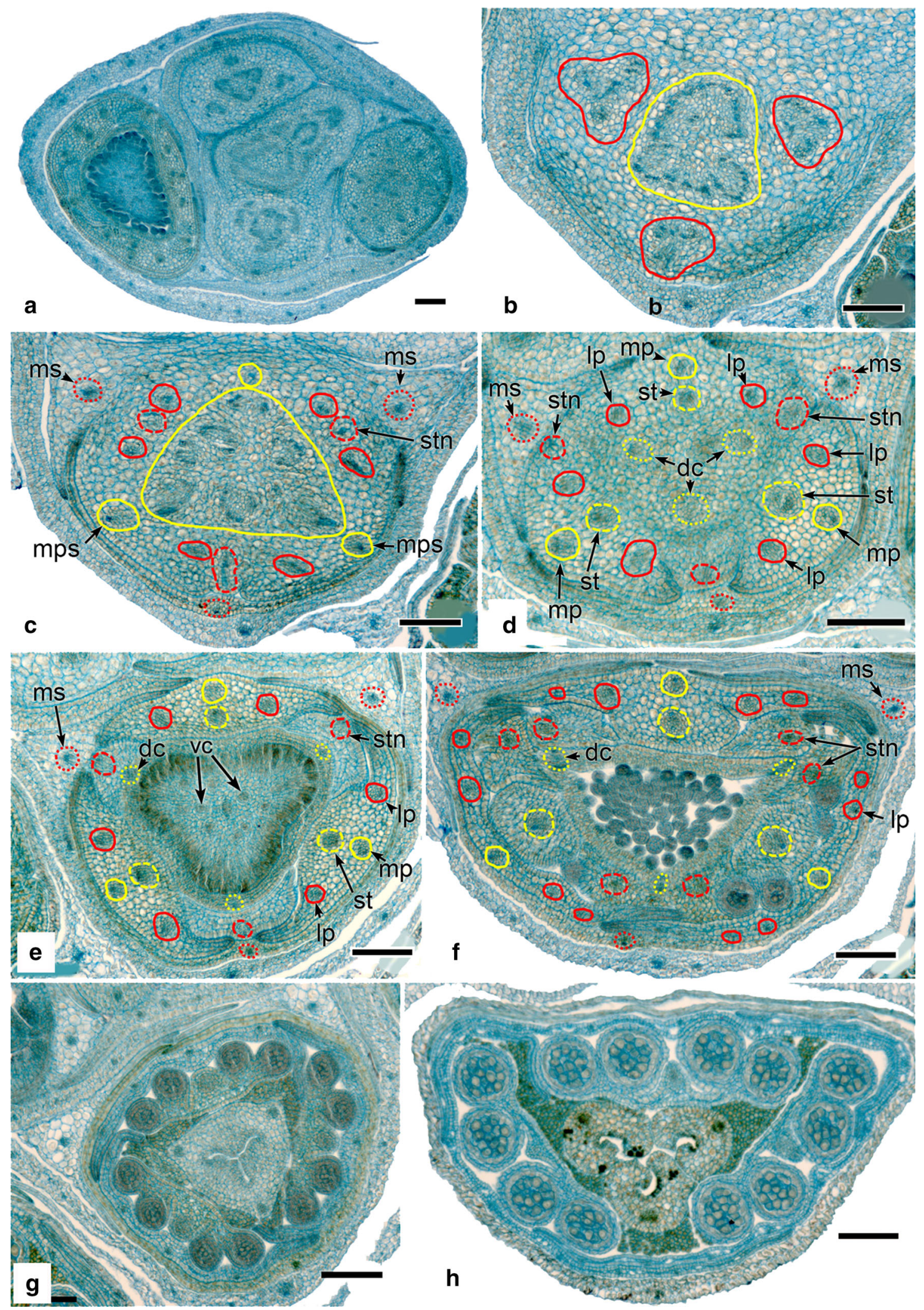
4Fig. 6 Xyris sp., wax-embedded sections (LM); a transverse section of an inflorescence axis, each flower enveloped by a single bract; $\mathbf{b}-$ $\mathbf{h}$ serial transverse sections of a single flower; $\mathbf{b}$ flower base with four groups of vascular bundles: three peripheral (outlined in red) and one central (outlined in yellow); c-f upper levels showing bundle divergence to supply floral organs; each peripheral (red) group has divided into four bundles that supply a sepal, a staminode and the lateral sides of contiguous petals; the central (yellow) group has divided into three median petal/stamen bundles and the dorsal and ventral carpellary bundles; g, h upper (distal) levels with three extrorse anthers and a single hollow style supplied by the dorsal carpellary bundle. Labels: $\mathrm{dc}=$ dorsal carpellary bundle; $1 \mathrm{p}=$ lateral petal bundle; $\mathrm{mp}=$ median petal bundle; $\mathrm{mps}=$ median petal/ stamen bundle; ms = median sepal bundle; st = stamen bundle; stn $=$ staminode $\quad$ bundle; $\quad \mathrm{vc}=$ ventral carpellary bundles. Bars $=100 \mu \mathrm{m}$

At the flower base, there is a ring of vascular bundles from which diverge the median and lateral sepal bundles (Fig. 10a) and the lateral petal bundles (Fig. 10a, b). The remaining bundles (encircled in yellow in Fig. 10d) provide the gynoecium vasculature (dorsal and ventral carpellary bundles) and the median petal bundles (Fig. 10b, c). As in the other genera, the median petal bundle divides at the median region of the ovary to supply the functional adnate stamens (Fig. 10d). The ventral carpellary bundles supply the placenta (Fig. 10ce), while the dorsal bundles run throughout the style and branch to supply both the stylar appendages and the stigma (Fig. 10f, g).

\section{Discussion}

\section{Floral character evolution in Poales}

A recent phylogenetic analysis using molecular data from $r b c L$ and $n d h F$ was relatively well sampled in terms of taxa (Bouchenak-Khelladi et al. 2014) and therefore allows greatly improved evaluation of character evolution in Poales, especially in the xyrid clade (Fig. 11). However, one monotypic genus, Achlyphila (A. disticha Maguire and Wurdack), has not yet been sequenced for molecular data; its placement is critical for analysis of character evolution in Xyridaceae. Achlyphila disticha is a rare species that grows in bogs at high altitudes (800-2300 m) in the Venezuelan Cerro Neblina; it is reportedly the only species of Xyridaceae in which the stamens are free from the petals (Kral 1992), though Carlquist (1960) illustrated the stamen bundles detaching from the petal bundles in this species. Achlyphila shares several flower, ovule and pollen characters with Abolboda, including characteristically sphaeroidal, inaperturate pollen; however, the pollen exine of Achlyphila lacks the characteristic spines of Abolboda grains, instead possessing only the small aggregated pila (rod-like rounded elements) that also occur on pollen of

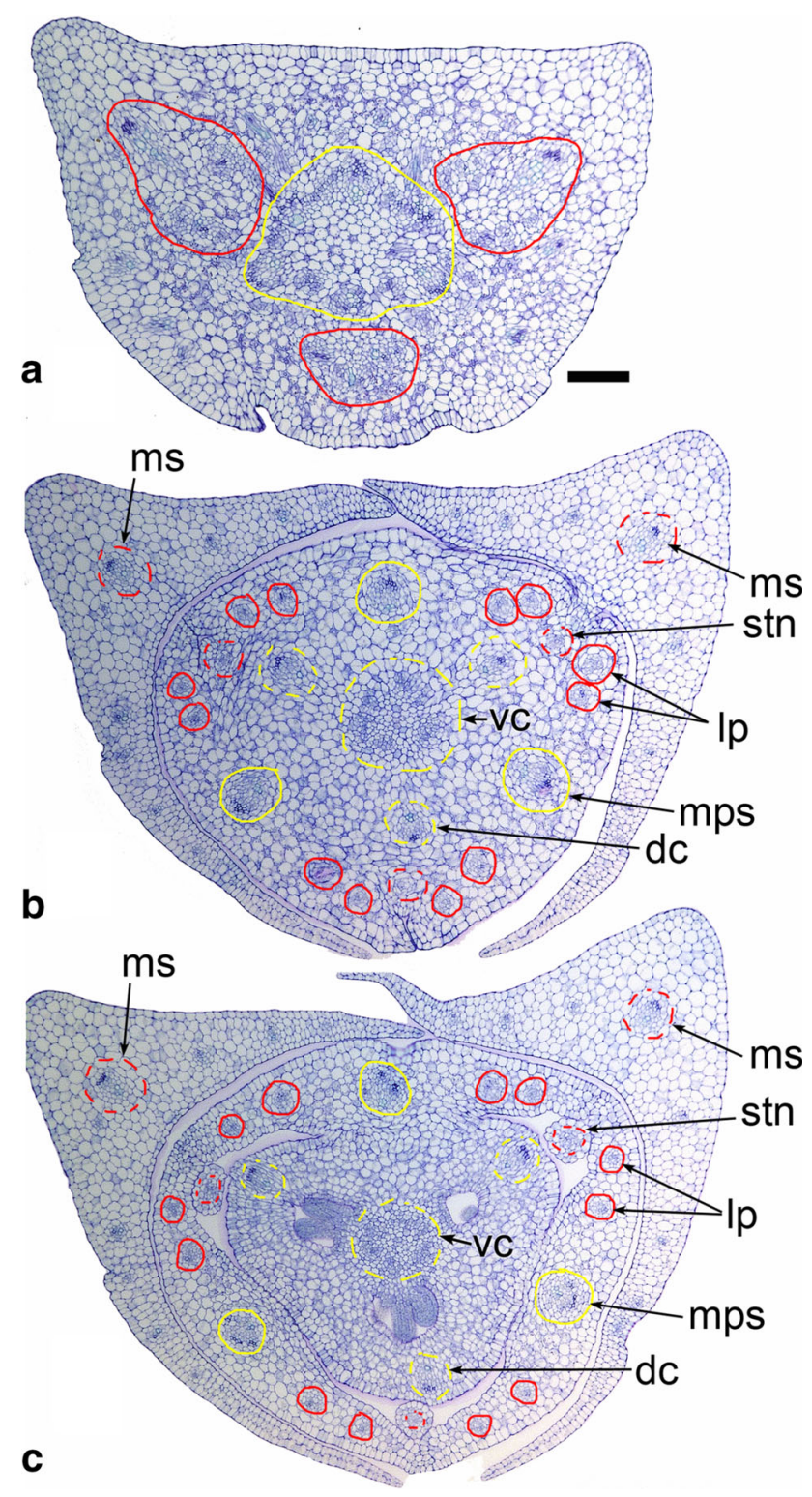

Fig. 7 Abolboda poarchon (a species with staminodes), serial transverse resin-embedded sections of a single flower (LM), below ovary in $\mathbf{a}, \mathbf{b}$, through ovary in $\mathbf{c} ; \mathbf{a}$ vascular bundles in four groups, three peripheral groups outlined in red and a central group outlined in yellow; in b, c, each peripheral (red) group has divided into six bundles (red circles): a median sepal bundle, a staminode bundle (stn) and two lateral bundles of contiguous petals; the central (yellow) group has divided into the median bundle of each petal that diverges at upper levels to supply the adnate stamen, three dorsal carpellary bundles and several carpellary bundles that will supply the ovules. Labels: $\mathrm{dc}=$ dorsal carpellary bundle; $1 \mathrm{p}=$ lateral petal bundle; $\mathrm{mps}=$ median $\mathrm{petal} / \mathrm{stamen}$ bundle; $\mathrm{ms}=$ median sepal bundle; $\mathrm{stn}=$ staminode bundle; $\mathrm{vc}=$ ventral carpellary vasculature . Bar $=100 \mu \mathrm{m}$

Xyris and other Xyridaceae (Carlquist 1960; Campbell 2012). The absence of stylar appendages, which is shared by Achlyphila and Xyris, is a plesiomorphic condition, so uninformative in this context. 

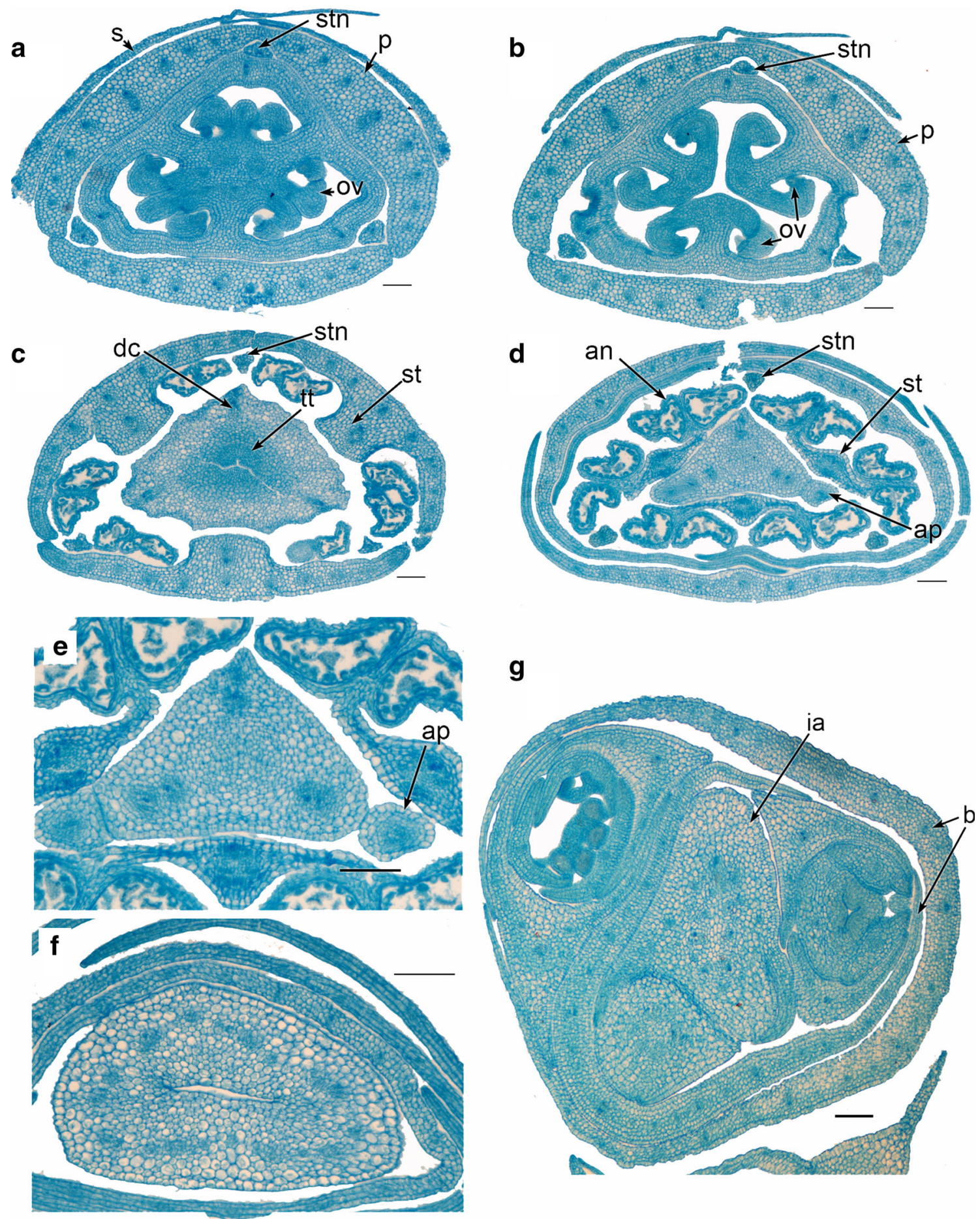

Fig. 8 Abolboda macrostachya (a species with staminodes), flowers in transverse section (LM); a-d serial sections through a flower from trilocular region near base of ovary (a), upper unilocular region of ovary (b), above ovary with stamens adnate to petals and transmitting tissue in style (c), region of insertion of stylar appendages (d); e upper, solid region of style with appendages; f more distal hollow

There is considerable evidence that both Xyridaceae and Eriocaulaceae are biotically pollinated (e.g. Ramos et al. 2005; Oriani et al. 2009), but further comparative data on

region of style with dorsal carpellary traces branching at this level; $\mathbf{g}$ inflorescence axis showing each flower enveloped by a single bract. Labels: $a n=$ anther; ap = stylar appendage; $b=$ bract; $d c=$ dorsal carpellary bundle; $i a=$ inflorescence axis; ov $=$ ovule; $p=$ petal; $\mathrm{s}=$ sepal; $\mathrm{st}=$ stamen; $\mathrm{stn}=$ staminode; $\mathrm{tt}=$ transmitting tissue. Bars $=100 \mu \mathrm{m}$

flowers of Eriocaulaceae are needed to understand floral character evolution among these two families. In Xyridaceae, two self-compatible Brazilian species of Abolboda 


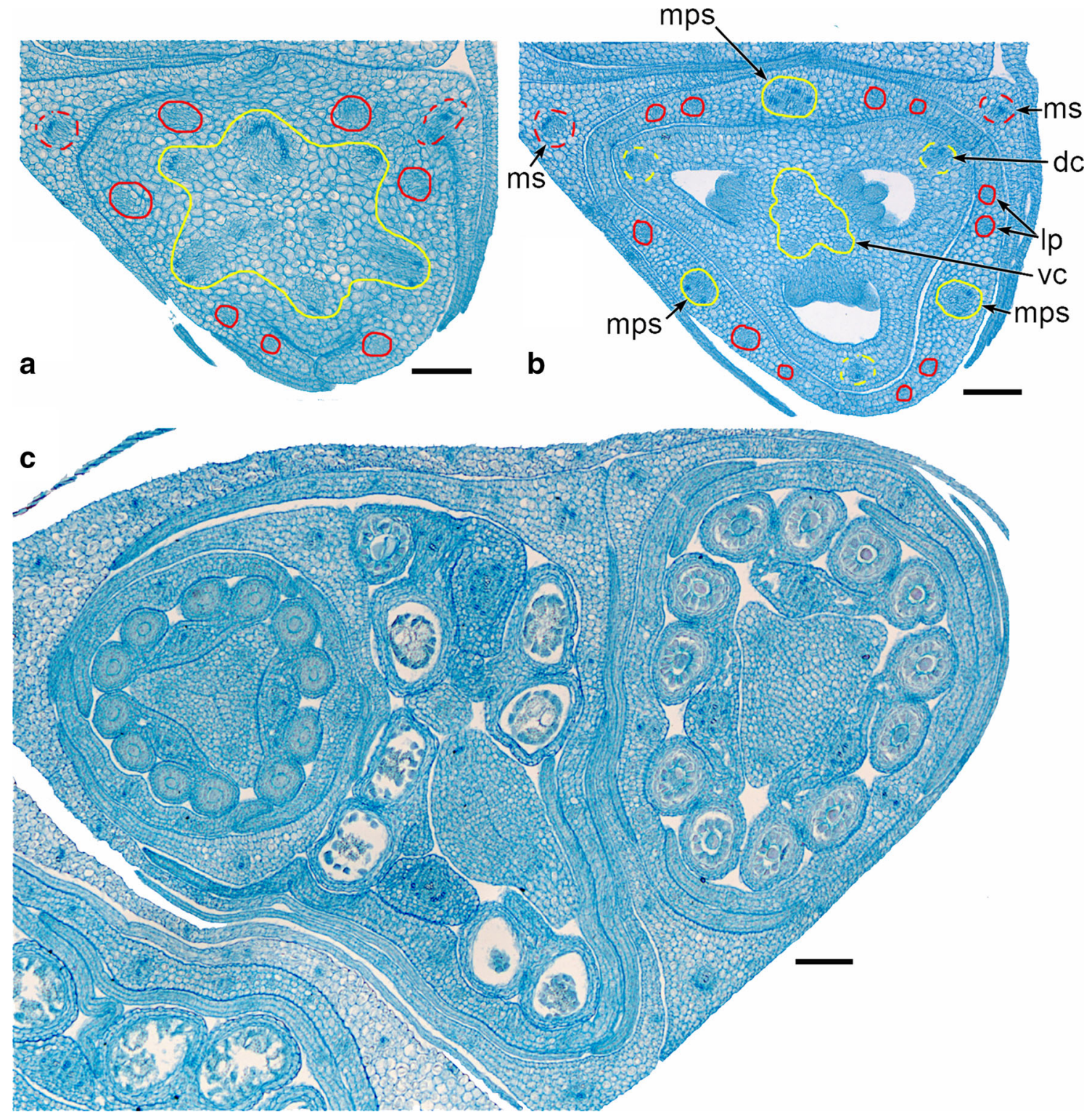

Fig. 9 Abolboda pulchella (a species without staminodes), flowers in transverse section (LM); a below ovary, outer bundles outlined in red, inner bundles outlined in yellow; b though ovary; c section through inflorescence with three developing flowers at different stages, each

are pollinated by bees that forage for nectar and pollen (Oriani and Scatena 2011), and two species of Xyris apparently offer only pollen as reward (Freitas and Sazima 2006).

The absence of septal nectaries in both Xyridaceae and Eriocaulaceae has prompted some authors to speculate that nectaries have evolved de novo in xyrids from ancestors that lacked septal nectaries (Linder and Rudall 2005). Our results show that the nectariferous stylar appendages that characterize some Xyridaceae (except Xyris and Achlyphila: Table 3) are vascularized by dorsal carpellary bundles and have a similar early ontogeny. In enclosed by a single bract. Labels: dc = dorsal carpellary bundle; $\mathrm{lp}=$ lateral petal bundle; $\mathrm{mps}=$ median petal/stamen bundle; $\mathrm{ms}=$ median sepal bundle; $\mathrm{vc}=$ ventral carpellary vasculature . Bars $=100 \mu \mathrm{m}$

Eriocaulaceae, nectariferous stylar appendages occur only in subfamily Paepalanthoideae; they are absent from Eriocauloideae (Stützel 1998; Rosa and Scatena 2007). Stützel (1990) observed that the stylar appendages of Abolboda share similar ontogeny with those of some Eriocaulaceae. The likely sister-group relationship between Eriocaulaceae and Xyridaceae would appear to indicate that stylar appendages are homologous between the two families. However, our optimization of this character strongly indicates that stylar appendages have evolved de novo in the two groups, regardless of the placement of Achlyphila (either as sister to Xyris or to the Abolboda clade). This 

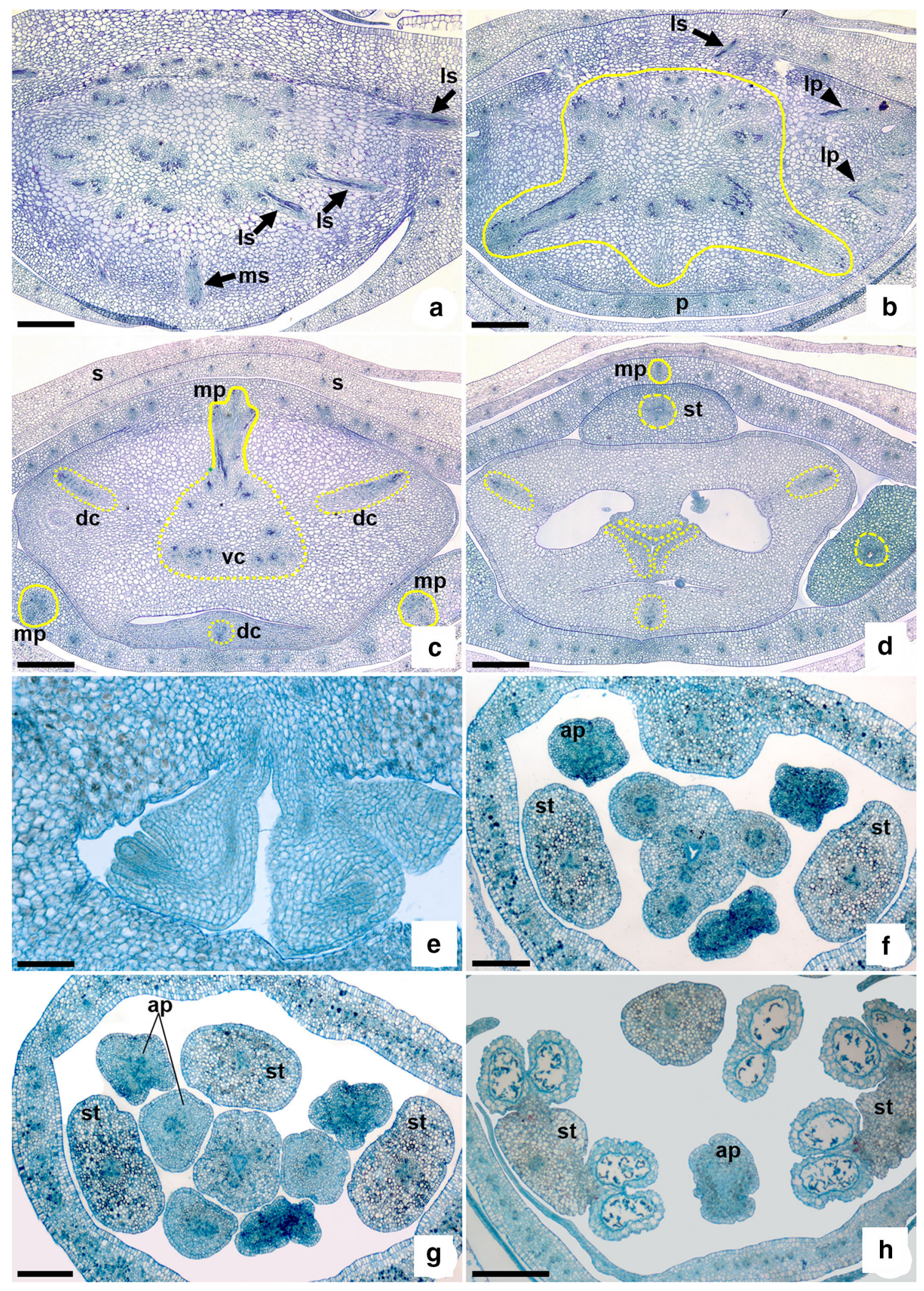
4Fig. 10 Orectanthe sceptrum, serial transverse sections through flower (LM), resin-embedded (a-d) and wax-embedded (e-h). ac Serial sections through a flower below the ovary, showing detachment of sepal and lateral petal bundles; $\mathbf{d}$ trilocular region of ovary; e detail of ovary showing anatropous tenuinucellate ovule. $\mathbf{f}-$ h Upper (distal) levels of flower, showing a stamen adnate to a petal in $\mathbf{f}$, and stamens free in $\mathbf{g}$, with introrse anthers in $\mathbf{h}$. Labels: ap = stylar appendage; $\mathrm{dc}=$ dorsal carpellary bundle; $\mathrm{lp}=$ lateral petal bundle; $\mathrm{mp}=$ median petal bundle; $\mathrm{ms}=$ median sepal bundle; $\mathrm{s}=$ sepal; $\mathrm{st}=$ stamen; $\quad \mathrm{vc}=$ ventral carpellary vasculature. Bars $=400 \mu \mathrm{m}$, except for $\mathbf{e}=100 \mu \mathrm{m}$ hypothesis (Fig. 11a) appears plausible because in Xyridaceae the stylar appendages are inserted at the style base (in Orectanthe) or mid-region (Abolboda) and are vascularized by ramifications of the dorsal carpel bundles; in contrast, in Paepalanthoideae (Eriocaulaceae) the stylar appendages are inserted either at the same level as the stigmatic branches (as in Syngonanthus) or below them (as in Leiothrix) and each receives the entire dorsal carpel bundle, leaving the stigma itself unvascularized (Stützel
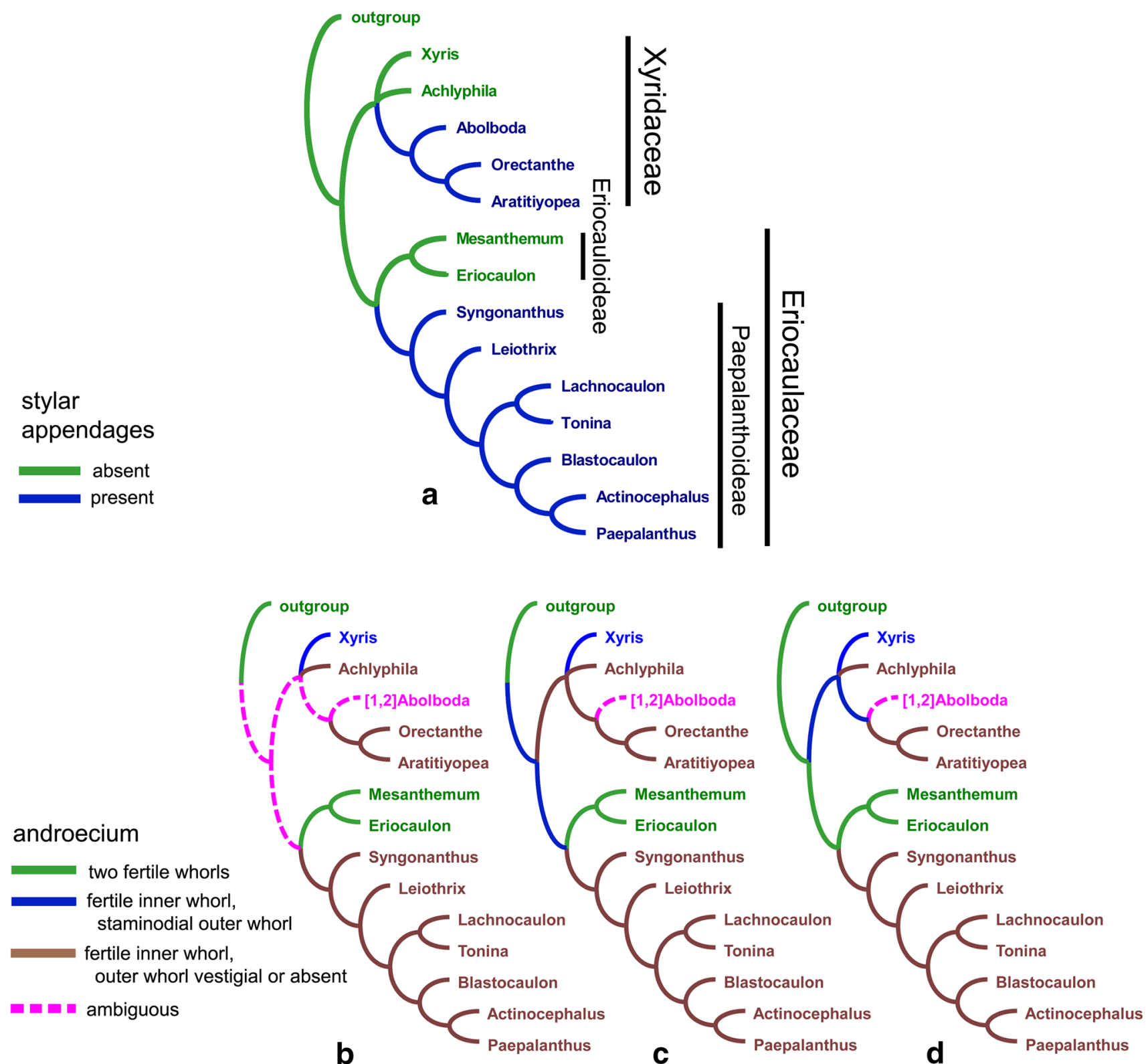

Fig. 11 Maximum parsimony optimizations of two characters (presence of stylar appendages and loss of fertile stamens) onto a phylogenetic tree diagram of the xyrid clade (Eriocaulaceae plus Xyridaceae). Phylogenetic relationships follow Bouchenak-Khelladi et al. (2014), with the additional inclusion of Achlyphila, which has not yet been sequenced, as discussed in the text. a Stylar appendages absent/present: all transitions are unambiguous. b-d Androecium: both androecial whorls fertile (0), inner whorl fertile and outer whorl consisting of prominent vascularized staminodes (1), inner whorl fertile, outer whorl vestigial or absent (2: scored for male flowers in Eriocaulaceae). b Unambiguous character state changes; $\mathbf{c}$ changes under accelerated (ACCTRAN) optimization; d changes under delayed (DELTRAN) optimization (d) 
1998; Rosa and Scatena 2003, 2007). Stützel and Gansser (1995) noted that stigma position differs between the two subfamilies of Eriocaulaceae: in Eriocauloideae the stigmas are in line with the carpels (i.e. they are carinal or dorsal), but in Paepalanthoideae the stigmas alternate with the dorsal stylar appendages (i.e. the stigmas are commisural). In Xyridaceae, both the stylar appendages and stigmas are carinal. Thus, the alternative hypothesis, that the stylar appendages are homologous between the two families, appears unlikely based on our data, but cannot be entirely discounted pending further comparative data on Eriocaulaceae. Because the stylar appendages produce nectar in both families (Rosa and Scatena 2007; Oriani and Scatena 2012), it is plausible to interpret them as a convergent character.

Comparative style anatomy indicates that modes of pollen-tube growth are unusually diverse among xyrids and other Poales, probably through variations in the degree of carpel fusion. The style is typically hollow in monocots, including Eriocaulaceae (Rosa and Scatena 2007) and Mayacaceae (Venturelli and Bouman 1986; Carvalho et al. 2009). In hollow styles, pollen tubes grow from the stigma to the ovary over the surface of the epidermis through a thin layer of mucilage (e.g. Rudall et al. 2005). In contrast, some Poales are characterized by solid styles with a pollentube transmitting tissue (PTTT), in which pollen tubes pass through an extracellular matrix. For example, among other Poales, a PTTT occurs in Flagellaria (Sajo and Rudall 2012) and some Poaceae, including the early divergent grasses Anomochloa and Streptochaeta (Sajo et al. 2012). Species of Xyridaceae differ with respect to this character. A PTTT occurs in the style branches of Xyris grandis (Remizowa et al. 2012), though it is not evident in the (different) Xyris species described here, which have hollow styles. The styles of both Abolboda and Orectanthe are solid in their upper regions (with a PTTT) but hollow at the style base, as a result of incomplete syncarpy.

\section{Loss of an entire stamen whorl}

Reduction of an entire stamen whorl occurs in ca $38 \%$ of angiosperm families, involving inner and outer whorls with equal frequency (Walker-Larsen and Harder 2000). The "missing" stamen whorl can be either entirely absent or transformed into sterile staminodial structures. Both conditions occur in Xyridaceae, in which outer whorl staminodes are absent from flowers of Achlyphila, Aratitiyopea and Orectanthe, present in Xyris, and either present or absent in different species of Abolboda (Table 3). In Xyris, the staminodes are large, vascularized, bifid and tipped with tufts of moniliform hairs; they could function as secondary pollen presenters, analogous with the rather similar staminodes of Commelina (Vogel 1978; Yeo 1992; Endress 1994;
Faden 2000). The staminodes that occur in seven (of 21) species of Abolboda are relatively inconspicuous. Thus, several families in Poales possess only a single fertile stamen whorl, at least in some species, including Mayacaceae and the cyperids, restiids, and xyrids.

The presence of a single androecial whorl contrasts with the majority of monocots (including another biotically pollinated family of Poales, Rapateaceae), which possess six fertile stamens in two equal whorls. However, this character varies within both Eriocaulaceae and Xyridaceae. In Xyris and Abolboda, the staminodes clearly represent the outer androecial whorl, alternating with the petals and fertile stamens. Within Eriocaulaceae, male flowers of subfamily Eriocauloideae have two fertile stamen whorls, whereas male flowers of Paepalanthoideae possess a single (inner) stamen whorl (Stützel 1998). Rosa and Scatena's (2003, 2007) reports of unvascularized scale-like structures in male flowers of some Paepalanthoideae were subsequently discounted by Silva et al. (2016), who reinterpreted these structures as petals at early stages of development.

The analysis of Bouchenak-Khelladi et al. (2014) differs from earlier molecular analyses in tentatively placing Mayacaceae close to Rapateaceae rather than to Xyridaceae and Eriocaulaceae, though their cyperid clade was not strongly supported (Fig. 1). This result makes sense in terms of morphological trait evolution because in Mayaca the three stamens are located opposite the outer tepals and hence represent the outer androecial whorl (e.g. Carvalho et al. 2009; Oriani and Scatena 2012), in contrast with Xyridaceae and most Eriocaulaceae, in which only the inner androecial whorl is fertile, thus representing an entirely independent morphological transition in Mayacaceae. On the other hand, it remains equivocal whether the loss of a fertile outer androecial whorl occurred more than once during the evolutionary history of the xyrid clade (Fig. 11c, d). The absence of staminodes from male flowers of Eriocaulaceae, together with the poorly known floral vasculature, makes it difficult to establish corolla and staminode homologies in Xyridaceae, especially given the ambivalent position of Achlyphila. Our optimization of this character within the xyrid clade (Fig. 11b-d) suggests that the transition from six to three fertile stamens occurred either once, followed by a reversal to six fertile stamens in Eriocauloideae and a staminodial outer whorl in some Xyridaceae (Fig. 11c), or twice independently in Xyridaceae and Eriocaulaceae (Fig. 11d); both hypotheses are equally parsimonious.

\section{Comparative floral vasculature}

In the Xyridaceae examined here, the petal bundles diverge at different flower levels in different species. Many 
Xyridaceae possess profound congenital fusion of some of their floral organs, forming a gamopetalous corolla tube in Orectanthe (Figs. 2g, 10f, g). In Orectanthe, which lacks staminodes, the lateral petal bundles diverge from the vascular ring that also supplies the sepals. Conversely, in the genera that include species with staminodes (Xyris and Abolboda), the vascular bundles that supply the lateral parts of each petal diverge from a vascular complex that provides both the median sepal and staminode bundles. In Abolboda, the lateral petal bundles have ramified. Even in species of Abolboda that lack staminodes (e.g. A. pulchella), the lateral petal bundles originate from the same vascular complex as the median sepal bundle. Thus, the lateral petal bundles appear to represent the "missing" outer stamen whorl, as hypothesized by Sajo et al. (1997). In this case, in Orectanthe and non-staminodial species of Abolboda, the petal could represent a compound organ composed of a single-traced petal that is fused congenitally with transformed petaloid staminodes. However, the presence of vascularized staminodes in Xyris and some species of Abolboda appears to refute this hypothesis. The relatively small flowers of Eriocaulaceae (the sister family to Xyridaceae) lack elaborate vasculature, so that the petals and sepals each receive a single tiny vascular bundle (Stützel 1998; Rosa and Scatena 2007).

Remizowa et al. (2012) suggested that the trimerous condition that predominates in monocot flowers could allow a broader base for each petal than in pentamerous flowers, perhaps facilitating the occurrence of three and multi-traced petals in some monocots. However, petal primordia in both Xyris and Abolboda are of similar size, despite the difference in vasculature (three bundles in Xyris and many in Abolboda). Fertile stamens are three and epipetalous in all Xyridaceae and some Eriocaulaceae (Stützel 1998). They diverge early from the petal primordium, and each receive a single vascular bundle diverged from the median petal bundle. In Xyris and Achlyphila, the stamen bundle diverges at the flower base, but in both Abolboda and Orectanthe, with a gamopetalous corolla (with stamens fused to the petals), it diverges at upper flower levels.

\section{Conclusions}

Our investigation provides the first comparative study of floral ontogeny and vasculature in Abolboda and Orectanthe, complementing previous work that reported an unusual pattern of perianth vasculature in Xyris species (Remizowa et al. 2012). We examined different species of Abolboda that either possess or lack staminodes. In species that possess them, staminode vasculature is closely associated with the lateral vasculature of each petal, potentially supporting an earlier hypothesis (Sajo et al. 1997) that the three "missing" stamens in Xyridaceae could have become incorporated into the corolla in the species that lack staminodes. Our investigation allows comparison of floral structures of other Poales of the xyrid clade in the context of a relatively well-resolved phylogenetic analysis (Bouchenak-Khelladi et al. 2014). Future studies will extend these comparisons to a broader-scale study of floral structures in Poales.

Acknowledgements The authors thank Yanis Bouchellak-Khelladi (University of Zurich) for kindly providing a species-level version of the Poales tree published in Bouchenak-Khelladi et al. (2014). We thank Louis Ronse de Craene and an anonymous reviewer for comments on the manuscript. We acknowledge the following financial support: GS received a fellowship from the Brazilian Conselho Nacional de Desenvolvimento Científico e Tecnológico (CNPq), AO received a funding from Fundação de Amparo à Pesquisa do Estado de São Paulo (FAPESP; grant number 2011/11536-3) and Coordenação de Aperfeiçoamento de Pessoal de Nível Superior (CAPES); VS received a grant from CNPq (number 301692/2010-6).

Open Access This article is distributed under the terms of the Creative Commons Attribution 4.0 International License (http://crea tivecommons.org/licenses/by/4.0/), which permits unrestricted use, distribution, and reproduction in any medium, provided you give appropriate credit to the original author(s) and the source, provide a link to the Creative Commons license, and indicate if changes were made.

\section{References}

Barrett CF, Baker WJ, Comer JR, Conran JG, Lahmeyer SC, Leebens-Mack JH, Li J, Lim GS, Mayfield-Jones DR, Perez L, Medina J, Pires JC, Santos C, Stevenson DW, Zomlefer WB, Davis JI (2015) Plastid genomes reveal support for deep phylogenetic relationships and extensive rate variation among palms and other commelinid monocots. New Phyt 209:855-870

Bouchenak-Khelladi Y, Muasya AM, Linder HP (2014) A revised evolutionary history of Poales: origins and diversification. Bot $\mathrm{J}$ Linn Soc 175:4-16

Campbell LM (2005) Contributions towards a monograph of Xyridaceae: a revised nomenclature of Abolboda. Harvard Papers Bot 10:137-145

Campbell LM (2012) Pollen morphology of Xyridaceae (Poales) and its systematic potential. Bot Rev 78:428-439

Campbell LM, Stevenson DW (2007) Inflorescence architecture and floral morphology of Aratitiyopea lopezii (Xyridaceae). Aliso 23:227-233

Carlquist S (1960) Anatomy of Guayana Xyridaceae: Abolboda, Orectanthe, and Achlyphila. Mem NY Bot Gard 10:65-117

Carvalho MLS, Nakamura AT, Sajo MG (2009) Floral anatomy of Neotropical species of Mayacaceae. Flora 204:220-227

Dahlgren RM, Clifford HT, Yeo PF (1985) The families of the monocotyledons. Springer, Berlin

Davis JI, Stevenson DW, Petersen G, Seberg O, Campbell LM, Freudenstein JV, Goldman DH, Hardy CR, Michelangeli FA, Simmons MP, Specht CD, Vergara-Silva F, Gandolfo M (2004) A phylogeny of the monocots, as inferred from rbcL and atpA sequence variation, and a comparison of methods for calculating jackknife and bootstrap values. Syst Bot 29:467-510 
Eames AJ (1931) The vascular anatomy of the flower with refutation of the theory of carpel polymorphism. Amer J Bot 18:147-188

Endress PK (1994) Diversity and evolutionary biology of tropical flowers. Cambridge University Press, Cambridge

Endress PK (2001) Origins of flower morphology. J Exp Zoology 291:105-115

Endress PK (2005) Links between embryology and evolutionary floral morphology. Curr Sci 89:749-754

Faden RB (2000) Floral biology of Commelinaceae. In: Wilson KL, Morrison D (eds) Monocots: systematics and evolution. CSIRO Publishing, Melbourne, pp 309-317

Freitas L, Sazima M (2006) Pollination biology in a tropical highaltitude grassland in Brazil: interactions at the community level. Ann Missouri Bot Gard 93:465-516

Givnish TJ, Ames M, McNeal JR, McKain MR, Steele PR, dePamphilis CW, Graham SW, Pires JC, Stevenson DW, Zomlefer WB, Briggs BG, Duvall MR, Moore MJ, Heaney JM, Soltis DE, Soltis PS, Thiele K, Leebens-Mack JH (2010) Assembling the tree of the monocotyledons: plastome sequence phylogeny and evolution of Poales. Ann Missouri Bot Gard 97:584-616

Kral R (1992) A treatment of American Xyridaceae exclusive of Xyris. Ann Missouri Bot Gard 79:819-885

Kral R (1998) Xyridaceae. In: Kubitzki K (ed) The families and genera of vascular plants. IV. Flowering plants-Monocotyledons. Alismatanae and Commelinanae (except Gramineae). Springer, Berlin, pp 197-207

Linder HP, Rudall PJ (2005) Evolutionary history of Poales. Annual Rev Ecol Evol Syst 36:107-124

Nixon KC (2002) WinClada, Vers. 1.00.08. Ithaca, New York. Published by the author (distributed through http://www. cladistics.com.)

Oriani A, Scatena VL (2011) Reproductive biology of Abolboda pulchella and $A$. poarchon (Xyridaceae: Poales). Ann Bot (Oxford) 107:611-619

Oriani A, Scatena VL (2012) Floral anatomy of xyrids (Poales): contributions to their reproductive biology, taxonomy, and phylogeny. Int J Pl Sci 173:767-779

Oriani A, Sano PT, Scatena VL (2009) Pollination biology of Syngonanthus elegans (Eriocaulaceae-Poales). Austal J Bot 57:94-105

Puri V (1951) The role of floral anatomy in the solution of morphological problems. Bot Rev 17:471-553

Ramos COC, Borba EL, Funch LS (2005) Pollination in Brazilian Syngonanthus (Eriocaulaceae) species: evidence for entomophily instead of anemophily. Ann Bot (Oxford) 96:387-397

Remizowa MV, Sokoloff DD, Rudall PJ (2010) Evolutionary history of the monocot flower. Ann Missouri Bot Gard 97:617-645

Remizowa MV, Kusnetsov AN, Kusnetsova SP, Rudall PJ, Nuraliev MS, Sokoloff DD (2012) Flower development and vasculature in
Xyris grandis (Xyridaceae: Poales), a case study for examining petal diversity in monocot flowers with a double perianth. Bot J Linn Soc 170:93-111

Ronse De Craene LP (2010) Floral diagrams. Cambridge University Press, Cambridge

Rosa MM, Scatena VL (2003) Floral anatomy of Eriocaulon elichrysoides and Syngonanthus caulescens (Eriocaulaceae). Flora 198:188-199

Rosa MM, Scatena VL (2007) Floral anatomy of Paepalanthoideae (Eriocaulaceae, Poales) and their nectariferous structures. Ann Bot (Oxford) 99:131-139

Rudall PJ, Sajo MG (1999) Systematic position of Xyris: flower and seed anatomy. Int J Pl Sci 160:795-808

Rudall PJ, Stuppy W, Cunniff J, Kellogg EA, Briggs BG (2005) Evolution of reproductive structures in grasses (Poaceae) inferred by sister-group comparison with their putative closest living relatives, Ecdeiocoleaceae. Amer J Bot 92:1432-1443

Sajo MG, Rudall PJ (2012) Morphological evolution in the graminid clade: comparative floral anatomy of the grass relatives Flagellariaceae and Joinvilleaceae. Bot J Linn Soc 170:393-404

Sajo MG, Wanderley MGL, Menezes NL (1997) Observações anatômicas sobre a vascularização floral em Xyris L. (Xyridaceae). Bol Bot Univ São Paulo 16:15-19

Sajo MG, Pabón-Mora N, Jardim J, Stevenson DW, Rudall PJ (2012) Homologies of the flower and inflorescence in the earlydivergent grass Anomochloa (Poaceae). Amer J Bot 99:624-628

Silva AL, Trovo M, Coan AI (2016) Floral development and vascularization help to explain merism evolution in Paepalanthus (Eriocaulaceae, Poales). PeerJ 4:e2811

Stuitzel T (1990) Appendices am Gynoecium der Xyridaceen Morphogenie, Funktion und sytematiche Bedeutung. Beit Biol Pfl 65:275-299

Stützel T (1998) Eriocaulaceae. In: Kubitzki K (ed) The families and genera of vascular plants. IV. Flowering plants-Monocotyledons. Alismatanae and Commelinanae (except Gramineae). Springer, Berlin, pp 197-207

Stützel T, Gansser N (1995) Floral morphology of North American Eriocaulaceae and its taxonomic implications. Feddes Repert 106:495-502

Venturelli M, Bouman F (1986) Embryology and seed development in Mayaca fluviatilis (Mayacaceae). Acta Bot Neerl 35:497-516

Vogel S (1978) Evolutionary trends in pollen flowers. In: Richards AJ (ed) The pollination of flowers by insects. Academic Press, New York, pp 89-104

Walker-Larsen J, Harder LD (2000) The evolution of staminodes in Angiosperms: patterns of stamen reduction, loss, and functional re-invention. Amer J Bot 87:1367-1384

Yeo PF (1992) Secondary pollen presentation: form, function and evolution. Springer, New York 